\title{
IDENTIFIKASI POTENSI INTERAKSI OBAT PADA PASIEN DIABETES MELITUS TIPE 2 RAWAT INAP DI RUMAH SAKIT GUNUNG MARIA TOMOHON PERIODE JANUARI - MEI 2018
}

\author{
Omega A. Poluan ${ }^{1)}$, Weny I. Wiyono ${ }^{1)}$, Paulina V. Y. Yamlean ${ }^{1)}$ \\ ${ }^{1)}$ Program Studi Farmasi FMIPA UNSRAT Manado, 95115
}

\begin{abstract}
Drug interaction are an event that can occur when the shared use of two or more drugs. The interactions of drugs can produce beneficial and adverse effects. Increasing of drug interaction incident resulted in unwanted effect might be caused by increased frequency of polypharmacy or multiple drugs. Type 2 diabetes mellitus patients are prone to infection, long wound healing time, and deteriorating eyesight, in addition to hypertension, hyperlipidemia, obesity, or other vascular and neuronal complication which are common in such patients. This study aims to identify the percentage of drug interaction potential based on patients number, mechanism, and severity level in type 2 diabetes mellitus inpatient at Gunung Maria Hospital from January to May 2018. This is a descriptive study and data were collected retrospectively from 46 medical records of type 2 diabetes mellitus patients who met the inclusion criteria. This study showed that 32 patients $(69.57 \%)$ potentially had drug interaction, with total of 55 potential incidence. Based on mechanism, 37 (67.27\%) potential incidence are linked to pharmacodynamics interaction and 18 (32.73\%) potential incidence related to pharmacokinetics interaction. Based on severity level, 7 major potential incidents (12.73\%), 32 moderate potential incidents (58.18\%), and 16 minor potential incidence (29.09\%) were found.
\end{abstract}

Keywords : Type 2 Diabetes Mellitus, Potential Drug Interaction, Inpatient

\begin{abstract}
ABSTRAK
Interaksi obat merupakan kejadian interaksi obat yang dapat terjadi bila penggunaan bersama dua macam obat atau lebih. Interaksi obat dapat menghasilkan efek yang menguntungkan dan merugikan. Meningkatnya kejadian interaksi obat dengan efek yang tidak diinginkan disebabkan oleh makin banyak dan seringnya terjadinya polypharmacy atau Multiple Drug. Penderita Diabetes Melitus Tipe 2 lebih mudah terkena infeksi, sukar sembuh dari luka, daya penglihatan makin buruk, dan umumnya menderita hipertensi, hiperlipidemia, obesitas, dan juga komplikasi pada pembuluh darah dan syaraf. Penelitian ini bertujuan untuk mengetahui persentase potensi interaksi obat yang terjadi berdasarkan jumlah pasien, mekanisme dan tingkat keparahan pada pasien Diabetes Melitus Tipe 2 di instalasi rawat inap RS Gunung Maria Tomohon periode Januari - Mei 2018. Penelitian ini merupakan penelitian deksriptif dengan pengambilan data secara retrospektif terhadap 46 data rekam medik pasien Diabates Melitus Tipe 2 rawat inap yang memenuhi kriteria inklusi. Hasil penelitian, dari 46 pasien Diabetes Melitus Tipe 2 terdapat 32 pasien $(69,57 \%)$ yang berpotensi mengalami interaksi obat dengan jumlah 55 potensi kejadian. Berdasarkan mekanisme, interaksi farmakodinamik 37 potensi kejadian $(67,27 \%)$ dan interaksi farmakokinetik 18 potensi kejadian $(32,73 \%)$, dengan tingkat keparahan major 7 potensi kejadian $(12,73 \%)$, moderate 32 potensi kejadian $(58,18 \%)$ dan minor sebanyak 16 potensi kejadian $(29,09 \%)$.
\end{abstract}

Kata Kunci : DM Tipe 2, Potensi Interaksi Obat, Rawat Inap 


\section{PENDAHULUAN}

Interaksi obat - obat merupakan kejadian interaksi obat yang dapat terjadi bila penggunaan bersama dua macam obat atau lebih (Katzung, 2007). Interaksi obat adalah keadaan dimana suatu zat mempengaruhi aktivitas obat, dimana dapat menghasilkan efek meningkat atau menurun (Bushra et al., 2011). Interaksi obat dianggap penting secara klinik bila berakibat meningkatkan toksisitas dan atau mengurangi efektivitas obat yang berinteraksi terutama bila menyangkut obat dengan batas keamanan yang sempit (indeks terapi yang rendah) (Mariam, 2016).

Diabetes Melitus (DM) adalah gangguan metabolisme yang ditandai dengan hiperglikemia yang berhubungan dengan abnormalitas metabolisme karbohidrat, lemak dan protein dan menyebabkan komplikasi kronis mikrovaskuler, makrovaskuler, dan neuropati (Sukandar et al., 2013). DM Tipe 2 mencapai 90-95\% dari keseluruhan popoluasi penderita diabetes. DM Tipe 2 bukan disebabkan oleh kurangnya insulin, tetapi karena sel - sel sasaran insulin gagal atau tak mampu merespon insulin secara normal. Penderita DM Tipe 2 lebih mudah terkena infeksi, sukar sembuh dari luka, daya penglihatan makin buruk, dan umumnya menderita hipertensi, hiperlipidemia, obesitas, dan juga komplikasi pada pembuluh darah dan syaraf (Depkes RI, 2005).

\section{Menurut International Diabetes} Federation (2017) Indonesia menempati peringkat keenam dari sepuluh daftar Negara berdasarkan tingkat kejadian diabetes tertinggi di dunia dengan jumlah kasus 10,3 juta kasus. Persentase DM di Indonesia pada tahun 2013 sebesar 1,5\% dan pada tahun 2018 meningkat menjadi
2,0\%. Provinsi Sulawesi Utara merupakan Provinsi ke-4 tertinggi terdiagnosis DM yaitu 3,1\% (Riskesdas, 2018). Kota Tomohon merupakan salah satu kota di Sulawesi Utara yang cukup tinggi diabetes melitus. Berdasarkan data dari Dinas Kesehatan Tomohon tahun 2016, jumlah kasus DM di Kota Tomohon berjumlah 286 dan penduduk Tomohon yang menderita sakit pada tahun 2015 yaitu 19,20\% (Susenas BPS, 2016).

Berdasarkan data mengenai persentase Diabetes Melitus di Sulawesi Utara, khususnya Kota Tomohon yang cenderung tinggi, serta permasalahan terkait polifarmasi yang sulit dihindari, maka diperlukan adanya pemantauan terapi obat pada pasien Diabetes Melitus, dengan melakukan penelitian interaksi obat terhadap pasien DM Tipe 2 di instalasi rawat inap Rumah Sakit Gunung Maria Tomohon sehingga dapat meminimalisir kemungkinan terjadinya efek yang tidak dikehendaki.

\section{METODOLOGI PENELITIAN}

\section{Waktu dan Tempat Penelitian}

Penelitian dilakukan pada bulan November 2018 - April 2019 di bagian Rekam Medik Rumah Sakit Gunung Maria Tomohon.

\section{Jenis Penelitian}

Penelitian ini merupakan jenis penelitian deskriptif dengan pengambilan data secara retrospektif yang didasarkan pada data rekam medik rawat inap pasien Diabetes Melitus Tipe 2 periode Januari Mei 2018 di Rumah Sakit Gunung Maria Tomohon.

\section{Alat dan Data \\ Alat dan data yang digunakan dalam penelitian ini yaitu alat tulis, lembar}


pengumpulan data, literatur terkait dan catatan rekam medik pasien rawat inap Rumah Sakit Gunung Maria Tomohon.

\section{Subyek Penelitian}

Subyek dalam penelitian ini yaitu pasien rawat inap di Rumah Sakit Gunung Maria Tomohon dengan diagnosis Diabetes Melitus Tipe 2 periode Januari Mei 2018, yang memenuhi kriteria inklusi.

\section{Besar Sampel}

Sampel dalam penelitian ini yaitu data rekam medik pasien Diabetes Melitus Tipe 2. Banyaknya sampel diperoleh dengan menggunakan rumus Slovin, yang diambil dari Sevilla (2007). Jumlah sampel minimal yang diambil dalam penelitian ini sebanyak 46 pasien.

\section{Analisis Data}

Data diambil secara retrospektif yang kemudian dianalisis dengan analisis unvariat atau analisis deskriptif dengan menggambarkan karakteristik pasien yang terdiri dari usia, jenis kelamin, jumlah diagnosa, dan jenis obat yang digunakan secara bersamaan, kemudian data diolah dengan menggambarkan kejadian interaksi obat menurut mekanisme interaksi obat dan tingkat keparahan dari rendah hingga berat pada pasien Diabetes Melitus Tipe 2 di instalasi rawat inap Rumah Sakit Gunung Maria Tomohon.

\section{HASIL}

Jumlah pasien rawat inap dengan penyakit Diabetes Melitus Tipe 2 di Rumah Sakit Gunung Maria Tomohon pada periode Januari 2018 - Mei 2018 berjumlah 85 orang. Penelitian ini dilakukan dengan mengumpulkan data rekam medik pasien. Sampel yang diambil sebanyak 46 pasien dari rekam medik pasien pada periode Januari - Mei 2018. Berdasarkan sampel tersebut, didapati hasil sebagai berikut:

\section{Karakteristik Pasien Berdasarkan Umur}

Tabel 1. Data Karakteristik Berdasarkan Umur Pasien

\begin{tabular}{ccc}
\hline Umur & $\begin{array}{l}\text { Jumlah } \\
\text { Penderita } \\
(\mathbf{n})\end{array}$ & $\begin{array}{l}\text { Persentase } \\
(\%)\end{array}$ \\
\hline $15-24$ tahun & 0 & 0 \\
$25-34$ tahun & 1 & 2,17 \\
$35-44$ tahun & 1 & 2,17 \\
$45-54$ tahun & 11 & 23,92 \\
$55-64$ tahun & 17 & 36,96 \\
$65-74$ tahun & 13 & 28,26 \\
$\geq 75$ & 3 & 6,52 \\
\hline Total & $\mathbf{4 6}$ & $\mathbf{1 0 0}$ \\
\hline
\end{tabular}

Karakteristik Pasien Berdasarkan Jenis Kelamin

Tabel 2. Data Karakteristik Berdasarkan Jenis Kelamin

\begin{tabular}{ccc}
\hline $\begin{array}{l}\text { Jenis } \\
\text { Kelamin }\end{array}$ & $\begin{array}{c}\text { Jumlah } \\
\text { Penderita(n) }\end{array}$ & $\begin{array}{l}\text { Persentase } \\
(\boldsymbol{\%})\end{array}$ \\
\hline Laki-Laki & 19 & 41,30 \\
Perempuan & 27 & 58,70 \\
\hline \multicolumn{1}{c}{ Total } & $\mathbf{4 6}$ & $\mathbf{1 0 0}$ \\
\hline
\end{tabular}

\section{Jumlah Obat per Hari Selama Pasien di} Rawat

Tabel 3. Jumlah Obat yang diberikan pada Pasien Diabetes Melitus Tipe 2 per Hari

\begin{tabular}{ccc}
\hline $\begin{array}{c}\text { Jumlah } \\
\text { Obat }\end{array}$ & $\begin{array}{c}\text { Jumlah } \\
\text { Pasien }\end{array}$ & $\begin{array}{c}\text { Persentase } \\
(\boldsymbol{\%})\end{array}$ \\
\hline$<5$ & 16 & 34,78 \\
$\geq 5$ & 30 & 65,22 \\
\hline Total & $\mathbf{4 6}$ & $\mathbf{1 0 0}$ \\
\hline
\end{tabular}


Potensi Interaksi Obat Berdasarkan Jumlah Pasien

Tabel 4. Data Potensi Interaksi Obat

\begin{tabular}{ccc}
\hline $\begin{array}{c}\text { Kejadian } \\
\text { Interaksi }\end{array}$ & $\begin{array}{c}\text { Jumlah } \\
\text { Pasien }\end{array}$ & $\begin{array}{c}\text { Persentase } \\
(\mathbf{\%})\end{array}$ \\
\hline Terjadi & 32 & $7^{69,5}$ \\
Interaksi & & \multicolumn{2}{|c}{30,4} \\
Tidak Terjadi & 14 & $3^{\text {Interaksi }}$ \\
Total & &
\end{tabular}

100

\section{Mekanisme Potensi Interaksi Obat}

Tabel 5. Data Mekanisme Potensi Interaksi Obat

\begin{tabular}{lll}
\hline $\begin{array}{l}\text { Mekanisme } \\
\text { Interaksi Obat }\end{array}$ & $\begin{array}{l}\text { Jumlah } \\
\text { Kejadian }\end{array}$ & $\begin{array}{l}\text { Persentase } \\
(\boldsymbol{\%})\end{array}$ \\
\hline Farmakodinamik & 37 & 67,27 \\
Farmakokinetik & 18 & 32,73 \\
\hline Total & $\mathbf{5 5}$ & $\mathbf{1 0 0}$ \\
\hline
\end{tabular}

\section{Tingkat Keparahan Potensi Interaksi} Obat

Tabel 6. Data Tingkat Keparahan Potensi Interaksi Obat

\begin{tabular}{ccc}
\hline $\begin{array}{c}\text { Tingkat } \\
\text { Keparahan }\end{array}$ & $\begin{array}{c}\text { Jumlah } \\
\text { Kejadian }\end{array}$ & $\begin{array}{c}\text { Persentase } \\
(\mathbf{\%})\end{array}$ \\
\hline Major & 7 & 12,73 \\
Moderate & 32 & 58,18 \\
Minor & 16 & 29,09 \\
\hline Total & $\mathbf{5 5}$ & $\mathbf{1 0 0}$ \\
\hline
\end{tabular}

\section{PEMBAHASAN}

\section{Karakteristik Pasien Berdasarkan Umur}

Berdasarkan Tabel 1, hasil penelitian menunjukkan bahwa pasien dengan penyakit DM Tipe 2 meningkat pada usia 45 - 54 tahun dengan persentase $23,92 \%$ dan jumlah pasien tertinggi berada pada umur 55 - 64 tahun yaitu sebanyak 17 pasien $(36,96 \%)$, hal ini terjadi karena prevalensi diabetes melitus akan meningkat sesuai dengan bertambahnya usia, dan persentase DM yang tertinggi terjadi pada usia 64 tahun (Riset Kesehatan Dasar, 2013). Seseorang yang telah menginjak usia $>45$ tahun terjadi peningkatan risiko penyakit DM karena faktor degeneratif yaitu menurunnya fungsi tubuh (Perkeni, 2011). Usia lebih dari 40 tahun merupakan usia yang beresiko terkena DM Tipe 2 dikarenakan adanya intoleransi glukosa dan proses penuaan yang menyebabkan kurangnya sel beta pankreas dalam memproduksi insulin (Trisnawati dan Setyorogo, 2013).

\section{Karakteristik Pasien Berdasarkan Jenis Kelamin}

Berdasarkan Tabel 2 dapat dilihat bahwa pasien yang berjenis kelamin laki laki sebanyak 19 pasien $(41,30 \%)$ dan pasien berjenis kelamin perempuan sebanyak 27 pasien (58,70\%). Hasil ini menunjukkan bahwa pasien diabetes melitus Tipe 2 di instalasi rawat inap Rumah Sakit Gunung Maria Tomohon, yang berjenis kelamin perempuan lebih banyak dibandingkan pasien yang berjenis kelamin laki - laki. Hal ini dikarenakan perempuan lebih berisiko mengidap diabetes karena secara fisik perempuan memiliki peluang peningkatan indeks masa tubuh yang lebih besar. Sindroma siklus bulanan (premenstrual syndrome), pasca menopause yang membuat distribusi lemak tubuh menjadi mudah terakumulasi akibat proses hormonal tersebut sehingga perempuan beresiko menderita Diabetes Melitus Tipe 2 (Cheekurthy, A.J.P., et al., 2016). Selain itu, gangguan menstruasi merupakan indikator penting yang menunjukan adanya gangguan fungsi sistem reproduksi yang dapat dihubungkan dengan peningkatan resiko berbagai penyakit seperti penyakit metabolik yaitu 
diabetes melitus. Hal tersebut dikarenakan terdapat dua hormon yang memiliki efek antagonis terhadap kadar glukosa darah yaitu reseptor hormon estrogen pada sel $\beta$ pankreas yang menyebabkan pelepasan insulin yang merupakan hormon terpenting dalam homeostatis glukosa dalam darah (Alonso-Magdalena, 2008).

\section{Jumlah Obat per Hari Selama Pasien di Rawat}

Berdasarkan Tabel 3 dapat dilihat jumlah obat perhari yang diterima oleh pasien Diabetes Melitus Tipe 2 di Rumah Sakit Gunung Maria Tomohon, sebanyak 16 pasien $(34,78 \%)$ menerima $<5$ obat perhari dan 30 pasien $(65,22 \%)$ menerima $\geq 5$ obat perhari. Dari penelitian ini, ditemukan pasien yang mendapat $\geq 5$ obat perhari merupakan hasil terbanyak. Kombinasi dari beberapa obat pada pasien DM Tipe 2 mungkin tidak dapat dihindari karena selain digunakan untuk mengendalikan kadar gula darah, obat obat tersebut juga digunakan sebagai upaya pengendalian dari beberapa komplikasi yang muncul pada penderita DM Tipe 2 (Kurniawan, 2010). Menurut penelitian Utami (2013) di Pontianak, disebutkan bahwa kejadian potensi interaksi obat 6 kali lebih besar pada resep yang mengandung jumlah obat $\geq 5$ dibandingkan dengan resep yang mengandung jumlah obat $<5$.

\section{Potensi Interaksi Obat Berdasarkan Jumlah Pasien}

Berdasarkan Tabel 4, diperoleh bahwa persentase pasien Diabetes Melitus Tipe 2 di instalasi rawat inap Rumah Sakit Gunung Maria Tomohon, lebih banyak yang berpotensi mengalami interaksi obat yaitu sebanyak 32 pasien $(69,57 \%)$, sementara yang tidak berpotensi mengalami interaksi obat sebanyak 14 pasien $(30,43 \%)$. Dari 32 pasien yang berpotensi mengalami interaksi obat, sebanyak 20 pasien berjenis kelamin perempuan dan 12 pasien berjenis kelamin laki - laki. Berdasarkan umur pasien yang berpotensi mengalami interaksi obat, 1 pasien berumur 25 - 34 tahun, 1 pasien berumur $35-44$ tahun, 10 pasien berumur 45 - 54 tahun, 10 pasien berumur $55-64$ tahun, 7 pasien berumur $65-74$ tahun dan 3 pasien berumur $\geq 75$ tahun

\section{Mekanisme Potensi Interaksi Obat}

Berdasarkan Tabel 5 terkait mekanisme potensi interaksi obat, diperoleh bahwa mekanisme interaksi obat yang paling berpotensi terjadi ialah mekanisme interaksi obat farmakodinamik, yaitu sebanyak 37 potensi kejadian $(67,27 \%)$. Hal ini menunjukkan bahwa efek dari suatu obat diubah oleh obat lain pada tempat aksinya.

Mekanisme potensi interaksi obat farmakodinamik terjadi pada kombinasi antara obat Metformin dan Glimepiride. Kombinasi kedua obat tersebut memiliki tingkat keparahan moderate. Penggunaan Metformin dan Glimepiride secara bersamaan dapat berpotensi meningkatkan risiko hipoglikemia atau gula darah rendah. Agar kedua obat tersebut dapat digunakan dengan aman, perlu dilakukan pemantauan gula darah yang sering (drugs.com, 2019). Kombinasi Metformin dan Glimepiride secara signifikansi dapat menurunkan glukosa darah puasa, glukosa darah post prandial, kadar HbA1c, dan kadar Hcy (homocysteine) (Hassan, 2015). Kombinasi Sulfonylurea (Glimepiride) dengan Biguanid (Metformin) merupakan kombinasi yang umum digunakan karena Sulfonylurea akan merangsang sekresi pankreas yang dapat memberikan 
kesempatan untuk senyawa Biguanid bekerja efektif, sehingga mempunyai efek saling menunjang. Khasiat keduanya akan menjadi semakin optimal dalam menekan hiperglikemia serta kelainan kardiovaskuler. Kombinasi Metformin dengan Glimepiride dapat menurunkan kadar glukosa darah lebih banyak daripada pengobatan tunggal masing - masing (Suyono, 2005).

Salah satu potensi interaksi obat dengan mekanisme farmakokinetik yaitu kombinasi antara obat Ondansetron dan Acetaminophen

(Paracetamol).

Penggunaan secara bersamaan obat Ondansetron dan Paracetamol termasuk dalam tingkat keparahan minor. Jika obat Paracetamol dikonsumsi secara bersamaan dengan Ondasetron, maka efek farmakologis dari paracetamol dapat diblokir dengan pemberian bersama Ondasetron (Lexicomp, 2019). Atas dasar teoretis Ondansetron (antagonis reseptor 5$\mathrm{HT}_{3}$ ) diharapkan untuk mengurangi penularan rasa sakit serotonin (5-HT) diperkirakan memengaruhi respons nyeri melalui reseptor $5-\mathrm{HT}_{3}$ presinaptik di sumsung tulang belakang (Baxter, 2010).

\section{Tingkat Keparahan Potensi Interaksi Obat}

Berdasarkan Tabel 6, diperoleh bahwa persentase tertinggi untuk potensi interaksi obat berdasarkan tingkat keparahan ialah tingkat keparahan moderate dengan persentase sebanyak $58,18 \%$ dengan jumlah potensi kejadian sebanyak 32 kejadian. Secara teoritis kategori ini berarti bahwa efek dari interaksi obat dapat memperburuk kondisi pasien dan perlu untuk mempertimbangkan obat alternatif yang tidak berinteraksi satu sama lain (Micromedex, 2013).
Potensi interaksi obat yang mengalami tingkat keparahan moderate yaitu penggabungan antara obat Meloxicam dan Glimepiride. Kombinasi kedua obat tersebut dapat berpotensi meningkatkan efek Glimeperid dan menyebabkan kadar gula darah terlalu rendah (Medscape, 2019). Meloxicam merupakan inhibitor dari enzim CYP2C9 sedangkan Glimepiride di dalam tubuh dimetabolisme oleh enzim CYP2C9. Meloxicam sebagai inhibitor enzim CYP2C9 dapat menghambat metabolisme Glimepiride sehingga dapat meningkatkan konsentrasi Glimepiride di dalam tubuh dan menimbulkan terjadinya efek hipoglikemia (Lacy, 2012). Meloxicam merupakan golongan obat NSAID dapat meningkatkan kerja Glimepiride, dengan cara meningkatkan pelepasan insulin melalui mekanisme penghambatan kanal ion kalium pada sel beta pankreas (Li et al., 2007).

Potensi interaksi obat dengan tingkat keparahan major salah satunya yaitu interaksi antara obat Ranitidin dan obat Metformin. Penggunaan bersama Ranitidin dan Metformin berpotensi meningkatkan efek Metformin dengan mengurangi pembersihan ginjal dengan cara menghambat sekresi Metformin di tubular ginjal sehingga kadar plasma Metformin dapat meningkat dan dapat meningkatkan efek farmakologisnya, sehingga disarankan untuk mengubah terapi (Medscape, 2019; Tatro, 2009). Menggunakan Metformin bersama dengan Ranitidine dapat berpotensi menyebabkan kondisi yang mengancam jiwa yang disebut asidosis laktat. Hal ini menyebabkan kelemahan, meningkatkan kantuk, detak jantung yang lambat, detak jantung yang lambat, nyeri otot, sesak 
nafas, sakit perut, pusing dan pingsan (drugs.com, 2019).

Potensi interaksi obat dengan tingkat keparahan minor efek yang ditimbulkan biasanya ringan atau mungkin tidak timbul dan tidak mempengaruhi outcome terapi dan tidak dibutuhkan terapi tambahan (Tatro, 2001). Interaksi obat dengan tingkat keparahan minor hanya memberikan sedikit pengaruh terhadap respon teraupetik obat, dampak klinis kurang signifikan dan tidak dibutuhkan adanya perubahan regimen terapi (Feinstein., et al., 2015).

\section{KESIMPULAN}

Dari hasil penelitian diperoleh kesimpulan sebagai berikut:

1. Dari 46 pasien Diabetes Melitus Tipe 2 di instalasi rawat inap RS Gunung Maria Tomohon, terdapat 32 pasien dengan persentase $69,57 \%$ yang berpotensi mengalami interaksi obat dengan jumlah 55 potensi kejadian interaksi.

2. Berdasarkan mekanisme interaksi obat pada pasien Diabetes Melitus Tipe 2 di instalasi rawat inap RS Gunung Maria Tomohon, interaksi farmakodinamik sebanyak 37 potensi kejadian dengan persentase $67,27 \%$ dan interaksi farmakokinetik sebanyak 18 potensi kejadian dengan persentase 32,73\%. Berdasarkan tingkat keparahan interaksi obat pada pasien Diabetes Melitus Tipe 2 di instalasi rawat inap RS Gunung Maria Tomohon, major sebanyak 7 potensi kejadian dengan persentase 12,73\%, moderate sebanyak 32 potensi kejadian dengan persentase 58,18\% dan minor sebanyak 16 potensi kejadian dengan persentase $29,09 \%$.

\section{SARAN}

1. Untuk peneliti selanjutnya agar melakukan penelitian dengan penerapan metode prospektif dan melakukan pengembangan identifikasi interaksi obat yang lebih sebih spesifik terkait dengan mekanisme dan tingkat keparahan interaksi obat yang dapat terjadi pada pasien Diabetes Melitus Tipe 2.

2. Untuk pihak Rumah Sakit Gunung Maria Tomohon adalah data penelitian tentang interaksi obat agar dapat digunakan sebagai bahan pertimbangan dan evaluasi terkait potensi interaksi obat yang dapat terjadi pada peresepan pasien, agar dapat menjadi sistem untuk deteksi dini potensi interaksi obat yang mungkin terjadi dan yang dapat membahayakan pasien.

3. Untuk masyarakat, agar lebih proaktif dalam mencari tahu informasi tentang potensi terjadinya interaksi obat apabila akan mengonsumsi beberapa jenis obat secara bersamaan

\section{DAFTAR PUSTAKA}

Alonso-Magdalena. P., Ropero. A.B., Carrera. M.P., Cederroth. C.R., Baquie. M., Gauthier. B.R., Nef. S., Enrico. S., and Nadal. A. 2008. Pancreatic Insulin Content Regulation by the Estrogen Receptor ERa. ERa Regulate Insulin Content. 3(4):1-8.

Badan Pusat Statistik Kota Tomohon. 2016.

http://tomohonkota.bps.go.id/inde x.php/Publikasi [Desember 2018].

Baxter, K. 2010. Stockley's Drug Interaction Ninth Edition. Pharmaceutical Press, China. 
Bushra Rabia, Nousheen Aslam, Arshad Yar Khan. 2011. 'Food-Drug Interactions'. Oman Medical Journal, 26(2).

Cheekurthy, A.J.P., Rambabul, C., dan Kumar, A. 2016. Prevalence of Type 2 Diabetes Mellitus among Woman and the Associated Risk Factors. Research \& Reveiews: $J$ Nurs Health Scie. 2:1-5.

Departemen Kesehatan Republik Indonesia. 2005. Pharmaceutical Care untuk Penyakit Diabetes Melitus. Bakti Husada, Jakarta.

Drugs.com. 2019. Drugs Interaction Checker (Online) www.drugs.com/drug_interaction s.html. [Mei 2019].

Feinstein, J., Dai, D., Zhong, W., Freedman, J. dan Feudtner, C. 2015. Potential Drug - Drug Interactions in Infant, Child and Adolescent Patients in Childrens's Hospitals. Pediatrics. 135: 100 .

Hassan, M.H. dan Abd-Allah, G.M. 2015. Effects of Metformin Plus Glicazide Versus Metformin Plus Glimepiride on Cardiovascular Risk Factors in Patients with Type 2 Diabetes Mellitus. Pakistan Journal of Pharmaceutical Science. 28:1723-1730.

IDF, 2017. IDF Diabetes Atlas Eight Edition. International Diabetes Federation.

Katzung, B. G. 2007. Basic \& Clinical Pharmacology, Tenth Edition. Lange Medical Publications, United States. 11-33.
Kemenkes RI. 2013. Riset Kesehatan Dasar : Riskesdas 2013. Kementerian Kesehatan Republik Indonesia. Jakarta.

Kemenkes RI. 2018. Riset Kesehatan Dasar : Riskesdas 2018. Kementerian Kesehatan Republik Indonesia, Jakarta.

Kurniawan. 2010. Diabetes Melitus Tipe 2 pada Usia Lanjut. Kedokteran Indonesia. 60(12)582.

Lacy, C.F., Amstrong, L.L., Goldman, M.P. and Lance, L.L. 2012. Drug Information Handbook. American Pharmacist Assosiation, Lexicomp.

Lacy, C.F., Amstrong, L.L., Goldman, M.P. and Lance, L.L. 2019. Drug Information Handbook. American Pharmacist Assosiation, Lexicomp.

Li, J., Zhang, N., Ye, B., Ju, W., Orser, B., Fox, J.E.M., Wheeler. M.B., Wang, Q., and Lu. W.Y. 2007. Non-steroidal Anti-inflamatory Drugs Increase Insulin Release from Beta Cells by Inhibitng ATP-sensitive potassium Channels. British Journal of Pharmacology. 151(4):483-493.

Mariam, S. 2016. Evaluasi Kejadian Interaksi Obat Pada Pasien Rwat Inap Geriatri Penderita Gagal Jantung. Sekolah Tinggi Ilmu Farmasi dan Industri, Bogor.

Medscape. 2019. Drugs Interaction Checker (Online). http://reference.medscape.com/dr ug-interactionchecker. [Maret 2019]. 
Micromedex. 2013. Drug Interactions. http://www.micromedexsolutions. com/micromedex2/4.34.0/WebHe $\mathrm{lp} /$ Tools/Interactions/Drug_Intera ctions_severity_definitions.htm. [September 2019].

Perkumpulan Endokrinologi Indonesia (PERKENI). 2011. Konsensus Pengelolaan dan Pencegahan Diabetes Melitus Tipe 2 di Indonesia, Jakarta.

Sevilla, C.G. 2007. Research Methods. Rex Printing Company, Quezon City.

Sukandar, E.Y., Andrajati, R., Sigit. I.J., Andyana, K.I., Setiadi. P.A., Kusnandar. $2013 . \quad$ Iso Farmakoterapi. ISFI Penerbitan, Jakarta.

Suyono, S. 2005. Buku Ajar Ilmu Penyakit Dalam, Jilid III Edisi IV. Balai Penerbit Fakultas Kedokteran, Universitas Indonesia, Jakarta.

Tatro, D.S. 2001. Drug Interaction Facts, $5^{\text {th }}$ edition. A Wolters Kluwer Company, St Louis Missouri.

Tatro, D.S. 2009. Drug Interaction Facts. Facts \&Comparisons : USA.

Trisnawati, S.K. dan Setyorogo, S. 2013. Faktor Risiko Kejadian Diabetes Melitus Tipe 2 di Puskesmas Kecamatan Cengkareng Jakarta Barat Tahun 2012. Jurnal Ilmiah Kesehatan. 5(1):1-5.

Utami, M.G. 2013. Analisis Potensi Interaksi Obat Antidiabetik Oral pada Pasien di Instalasi Rawat Jalan Askes Rumah Sakit Dokter Soedarso Pontianak Periode Januari - Maret 2013 [skripsi]. Fakultas Kedokteran, Pontianak. 